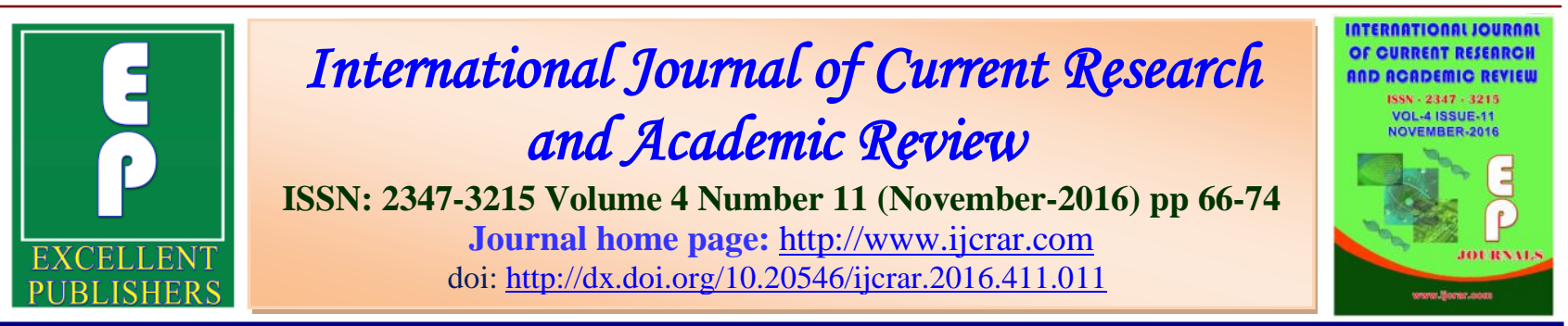

\title{
Biosorption of Heavy Metals in the Environment-A Review Paper
}

\author{
P. Kalyani* and K.P.J. Hemalatha \\ Department of Microbiology, Andhra University, Visakhapatnam, India \\ *Corresponding author
}

KEYWORDS
Biosorption,
Adsorption,
Heavy Metals,
Microbes.

A B $\quad \mathbf{S}$ T $\mathbf{R}$ A $\mathbf{C}$ T

Industrial effluents containing heavy metals may consider a major source of contamination causes serious environmental problems. Decontamination of heavy metals from wastewater has been a challenged for a long time. A number of methods have been developed for removal of toxic metal ions from wastewaters such as precipitation, evaporation, electroplating, ion exchange, membrane processes, etc. However, these conventional technologies are providing expensive due to non- regenerable materials used, high cost and generation of toxic sludge. Biosorption is a process which represents a biotechnological innovation as well as a cost effective excellent tool for removing heavy metals from aqueous solutions. It represents a typical technique for using economical alternate biological materials for the purpose. Today, biosorption is one of the main components of environmental and bioresource technology. Application of microorganisms (specifically bacteria, algae, yeasts and fungi) as biosorbents for heavy metal removal have received growing interest due to high surface to volume ratio; large availability, rapid kinetics of adsorption and desorption and low cost. The aim of the present study is to review the removal of heavy metals from aqueous solutions using various materials of biological origin such as fungi, algae, yeast and bacterial biomass. This review discuss the significance of heavy metal removal from waste streams and provides brief overview of potential of biosorbents and biosorption technology, highlights the undelaying features of biosorption and the operation conditions such as $\mathrm{pH}$, dose required, initial concentration, temperature, and treatment performance.

\section{Introduction}

Heavy metal pollution has become one of the major environmental problems that pose serious health hazard (Aktan et al., 2013). Different type industries use different type of heavy metals and directly or indirectly discharge wastewater containing toxic substances into the environment (Glombitza et al., 2014). Trace amounts of heavy metals are required by living organism including copper, iron, zinc but however excessive 
levels of these metals can be toxic to the organism due to their toxicity and accumulation behavior (Franke et al., 2003). Different methods have being used to decontaminate the environment from adverse effect of these pollutants but yet most of the methods used are not cost effective and far away from their best possible performance (Zabochnicka-ÅšwiÄ tek et al., 2014). Consequently the need to replace with biological method with are cheap and efficient method of treating metal-bearing effluents as these method may provide a possible way out to metal removal from contaminated environment (Pandit et al., 2013).

In recent years, microbial biomass has emerged as an option for developing economic and eco-friendly wastewater treatment process., therefore, applying biotechnology in controlling and removing metal pollution has been paid much attention, and gradually becomes hot topic in the field of metal pollution control because of its potential application. Alternative process is a biosorption, which utilizes various certain natural materials of biological origin, including bacteria, fungi, yeast, algae, etc. (Wang et al., 2009) Biosorption can be defined as the ability of biological materials to accumulate heavy metals from wastewater through metabolically mediated or physico-chemical pathways of uptake (Fourest et al., 1992). Biosorption, which is the ability of certain microbial biomaterials to bind and concentrate heavy metals from even the most dilute aqueous solutions, offers a technically feasible and economically attractive alternative (Petersen et al., 2005) Biosorption $^{\text {ee }}$ has been defined as the property of certain biomolecules (or types of biomass) to bind and concentrate selected ions or other molecules from aqueous solutions (Volesky et al., 2007). Algae, bacteria and fungi and yeasts have proved to be potential metal biosorbents (Volesky et $a l .$, 1994). It is consider an ideal alternative method for removing contaminates from effluents Biosorption is a rapid phenomenon of passive metal sequestration by the nongrowing biomass/adsorbents. It has advantages compared with conventional techniques (Volesky et al., 1995)., some of these are listed: (low cost; high efficiency; minimization of chemical and or biological sludge; no additional nutrient requirement; regeneration of biosorbent; and possibility of metal recovery). The biosorption process involves a solid phase (sorbent or biosorbent; adsorbent; biological material) and a liquid phase (solvent, normally water) containing a dissolved species to be sorbet (adsorbate, metal). Due to the higher affinity of the adsorbent for the adsorbate species, the latter is attracted and bound there by different mechanisms. The process continues till equilibrium is established between the amount of solid-bound adsorbate species and its portion remaining in the solution. The degree of adsorbent affinity for the adsorbate determines its distribution between the solid and liquid phases (Ahalya et al., 2003).

\section{Heavy metals}

Heavy metal ions have great effects on all forms of life. Heavy metal pollution is one of the most important environmental problems today because of their toxicity, bio-accumulation tendency, threat to human life and the environment (Igwe et al., 2003). Heavy metals are presented in nature and industrial waste water, so the presence of heavy metals in surface and ground water pose a contamination problem. Large number of industries can produce and discharge wastes containing different heavy metals into the environment. The main source of heavy metal pollution are metal 
plating, mining, smelting, battery manufacturing, tanneries, petroleum refining, pigment manufacture, printing paint manufacture, pesticides, etc. The main elements that considered as a heavy metals are chromium $(\mathrm{Cr})$, manganese $(\mathrm{Mn})$, cobalt $(\mathrm{Co})$, copper $(\mathrm{Cu})$, zinc $(\mathrm{Zn})$, molybdenum (Mo), mercury(Hg), nickel(Ni), tin(Sn), lead $(\mathrm{Pb})$, cadmium $(\mathrm{Cd})$, antimony $(\mathrm{Sb})$, etc. Three kinds of heavy metals are of concern, including toxic metals (such as $\mathrm{Hg}, \mathrm{Cr}, \mathrm{Pb}$, $\mathrm{Zn}, \mathrm{Cu}, \mathrm{Ni}, \mathrm{Cd}, \mathrm{As}, \mathrm{Co}, \mathrm{Sn}$, etc.), precious metals (such as Pd, Pt, Ag, Au, Ru etc.) and radionuclides such as $\mathrm{U}, \mathrm{Th}, \mathrm{Ra}, \mathrm{Am}$, etc. (Wang et al., 2009; Wang et al., 2006) Lead, mercury, cadmium and chromium (VI) are at the top on the toxicity list from among various metal ions, the first three, called "the big three", are in the limelight due to their major impact on the environment (Volesky et al., 1994). Heavy metals are natural components from the earth ${ }^{\text {ee }}$ c crust. They cannot be destroyed or degraded. However, most of these heavy metals become toxic at high concentrations due to their ability to accumulate in living tissues. Removal of heavy metals from industrial wastewater is of primary importance. Cadmium, zinc, copper, nickel, lead, mercury and chromium are often detected in industrial wastewaters.

\section{Copper}

Copper, one of the most widely used heavy mental, is mainly employed in, electrical, electroplating industries, and in larger amounts is extremely toxic to living organisms. The presence of copper (II) ions causes serious toxicological concerns, it is usually known to deposit in brain, skin, liver, pancreas and myocardium (Davis et al., 2000). Copper usually occurs in nature as oxides and sulphides. Copper is an essential substance to human life. Copper is found in a variety of enzymes and is used for biological electron transport. Like all heavy metals, it is potentially toxic, especially at high concentrations. Environmental contamination due to copper is caused by mining, printed circuits, metallurgical, fiber production, pipe corrosion and metal plating industries (Barrell et al., 1975). The other major industries discharging copper in their effluents are paper and pulp, petroleum refining and wood preserving. Agricultural sources such as fertilizers, fungicidal sprays and animal wastes also lead to water pollution due to copper. Copper may be found as a contaminant in food, especially shell fish, liver, mushrooms, nuts and chocolates. Any packaging container using copper material may contaminate the product such as food, water and drink (Pendias et al., 1992).In some instances, exposure to copper has resulted in jaundice and enlarged liver. It is suspected to be responsible for one form of metal fume fever (Wagoner et al., 1976). Containing is linked to an increase in lung cancer among exposed workers (Onundi et al., 2010).

\section{Chromium}

There are two stable oxidation states of chromium found in the environment, $\mathrm{Cr}$ (III) and $\mathrm{Cr}$ (VI) which have contrasting toxicities, mobility and bioavailability. Chromium compounds of oxidation state Cr6+ are powerful oxidants. Chromium hexavalent (VI) compounds are used as pigments for Photography, and in pyrotechnics, dyes, paints, inks, and plastics. They can also be used for stainless steel production, textile dyes, wood preservation, leather tanning, and as anti-corrosion coatings. While $\mathrm{Cr}$ (III) is relatively innocuous and immobile, $\mathrm{Cr}$ (VI) moves readily through soils and aquatic environments and is a strong oxidizing agent capable of being absorbed through the skin. 
Int.J.Curr.Res.Aca.Rev.2016; 4(11): 66-74

Trivalent chromium, Cr (III), is an essential element required for normal carbohydrate and lipid metabolism.

\section{Lead}

Lead is a heavy metal poison which forms complexes with Oxo-groups in enzymes to affect virtually all steps in the process of hemoglobin synthesis and porphyria metabolism (Ademorat 1996). Toxic levels of lead in human have been associated with encephalopathy, seizures and mental retardation (Schumann et al., 1990).

\section{Cadmium}

The most severe form of $\mathrm{Cd}$ toxicity in humans is "itai-itai", a disease characterized by excruciating pain in the bone (Kasuya et al., 1992; Yasuda et al., 1995). Other health implications of $\mathrm{Cd}$ in humans include kidney dysfunction, hepatic damage and hypertension (Klaassen et al., 2001).However, it has been suggested that overall nutritional status (rather than mere $\mathrm{Cd}$ content of food) is a more critical factor in determining $\mathrm{Cd}$ exposure.

\section{Biosorption by Microbes}

Biosorption can be defined as the removal of metal or metalloid species, compounds and particulates from a solution by low cost biological materials (Wang et al., 2009).All biological materials can be useful biosorbents for metals sequestration with the exception of mobile alkali metal cations like sodium and potassium ions, and this can be a significant passive process in living and dead organisms (Gadd et al., 2010) several cheap biosorbents for the removal of metals mainly arrive under the following categories: bacteria, fungi, algae, plants, industrial wastes, agricultural wastes and other polysaccharide materials (Kumar et al., 2014). In general, all types of biomaterials used for biosorption were found to have good biosorption capacities towards all types of metal ions.

\section{Mechanism Involved in Biosorption}

Microbes are organisms that are capable of tolerating unfavorable circumstances, and these mechanisms evolved for the past millions of years (Hrynkiewicz et al., 2014).The ability of microorganisms, example bacteria, fungi, algae and plants biomass to remove heavy metal ions and radionuclide and, or to promote their transformation to less toxic forms has attract the attention of various environmental scientist, engineers and biotechnologist for many decades. Therefore, various concepts for bio-removal of heavy metals from waste streams and bioremediations of contaminated environment are being anticipated, some of which were brought to pilot or industrial level (Baker et al., 2000; Chaney et al., 2007; Macek et al., 2008; Muyzer et al., 2008; Singh et al., 2008).

There are many mechanism involve in biosorption some are not fully understood. Biosorption mechanism may be classified according to dependence on the cell's metabolism which is called metabolism dependent or according to the location where the metal removed from solution is found which is called Non -metabolism dependent/ metabolism independent like extra cellular accumulation/ precipitation, Cell surface sorption/ precipitation and Intracellular accumulation(

Davis et al., 2003; Neethu et al., 2015).During metabolism independent, metal uptake is by physicochemical interaction between the metal and the functional groups present on the microbial cell surface. 
Int.J.Curr.Res.Aca.Rev.2016; 4(11): 66-74

Table.1 Type of heavy metals and effects of human beings

\begin{tabular}{|c|c|c|c|}
\hline Heavy metal & Major source & Toxic effect & References \\
\hline Lead & $\begin{array}{l}\text { Mining, paint, } \\
\text { pigments, } \\
\text { electroplating, } \\
\text { manufacturing } \\
\text { batteries, burning of } \\
\text { coal }\end{array}$ & $\begin{array}{l}\text { Anemia, } \\
\text { damage, anorain } \\
\text { malaise, loss of } \\
\text { appetite, } \\
\text { kidney, } \\
\text { gastrointestinal } \\
\text { damage, } \\
\text { mental retardation in } \\
\text { children }\end{array}$ & $\begin{array}{l}\text { Chen et al., 1998; } \\
\text { Godt et al., } 2007\end{array}$ \\
\hline Copper & $\begin{array}{l}\text { Plating, } \quad \text { copper } \\
\text { polishing, } \\
\text { printing operations }\end{array}$ & $\begin{array}{l}\text { neurotoxicity, and } \\
\text { acute toxicity, } \\
\text { dizziness, diarrhea }\end{array}$ & Sharma et al 1995 \\
\hline Cadmium & $\begin{array}{l}\text { Plastic, welding, } \\
\text { pesticide, fertilizer, } \\
\text { mining, refining }\end{array}$ & $\begin{array}{l}\text { Kidney damage, } \\
\text { bronchitis, } \\
\text { Gastrointestinal } \\
\text { disorder, bone } \\
\text { marrow, cancer, lung } \\
\text { insufficiency, } \\
\text { hypertension, Itai-Itai } \\
\text { disease, weight loss }\end{array}$ & Singh et al., 2006; \\
\hline Zinc & $\begin{array}{l}\text { Mining, refineries, } \\
\text { brass manufacturing, } \\
\text { plumping }\end{array}$ & $\begin{array}{l}\text { Causes short term } \\
\text { ",metal-fume fever", } \\
\text { gastrointestinal } \\
\text { distress }\end{array}$ & Manohar et al., 2002 \\
\hline Mercury & $\begin{array}{lr}\text { Batteries, } & \text { paper } \\
\text { industry, } & \text { paint } \\
\text { industries, mining }\end{array}$ & $\begin{array}{l}\text { Damage to nervous } \\
\text { system, protoplasm } \\
\text { poisoning, corrosive to } \\
\text { skin, eyes, muscles, } \\
\begin{array}{l}\text { dermatitis, kidney } \\
\text { damage }\end{array}\end{array}$ & Ozturk, et al., 2007 \\
\hline Nickel & $\begin{array}{l}\text { Porcelain enameling, } \\
\text { non-ferrous metal, } \\
\text { paint formulation, } \\
\text { electroplating }\end{array}$ & $\begin{array}{l}\text { Chronic bronchitis, } \\
\text { reduced lung function, } \\
\text { lung cancer, }\end{array}$ & Robertson et al., 1989 \\
\hline Arsenic & $\begin{array}{l}\text { Smelting, mining, rock } \\
\text { sedimentation, } \\
\text { pesticides, }\end{array}$ & $\begin{array}{l}\text { Bronchitis, dermatitis, } \\
\text { bone } \\
\text { marrow depression, } \\
\text { hemolysis, } \\
\text { hepatomegaly, }\end{array}$ & $\begin{array}{l}\text { Granados-Correa } \\
\text { al., } 2009\end{array}$ \\
\hline Chromi -um & $\begin{array}{l}\text { Textile, dyeing, paints } \\
\text { and pigments, steel } \\
\text { fabrication }\end{array}$ & $\begin{array}{l}\text { Carcinogenic, } \\
\text { mutagenic, } \\
\text { teratogenicity, } \\
\text { epigastria pain } \\
\text { nausea, vomiting, } \\
\text { severe diarrhea, } \\
\text { producing lung tumors }\end{array}$ & Gadd et al., 2010 \\
\hline
\end{tabular}


This is based on physical adsorption, ion exchange and chemical sorption, which is not dependent on the cells' metabolism (Ahalya et al., 2003).

\section{Bacteria as Biosorbents of Heavy Metals}

Bacterial biosorption is mainly used for the removal of pollutants from effluents contaminated with pollutants that are not biodegradable, like metals ions and dyes. However, their isolation, screening and harvesting on a larger scale may be complicated but still remain one of the efficient way of remediating pollutants. Different bacterial strains were used for the removal of different metal ions. Bacteria have evolved a number of efficient systems for detoxifying metals ions they develop these resistance mechanisms mostly for their survival.

\section{Algae as Biosorbents of Heavy Metals}

Algae are efficient and cheap biosorbents as the requirement of nutrient by algae is little. Based on statistical analysis on algae potentiality in biosorption, it has been reported that algae absorb about $15.3 \%$ $84.6 \%$ which is higher as compared to other microbial biosorbents. In all the type of algae brown algae was known to have high absorption capacity. Biosorption of metal ions occurs on the cell surface by means of ion exchange method. Brown marine algae has the capacity to absorbed metals like $\mathrm{Cd}$, $\mathrm{Ni}, \mathrm{Pb}$ through chemical groups on their surface such as carboxyl, Sulfonate, amino, as well as sulfhydryl.

\section{Fungi as Biosorbents of Heavy Metals}

The use of fungi as bio sorbents material has been shown to be efficient material is also one of the cost-effective and eco-friendly methods with serves as an alternative to chemically bound treatment process. The capability of the many type of fungi to produce extracellular enzymes for the assimilation of complex carbohydrates for former hydrolysis makes capable the degradation of various degrees of pollutants. They also have the benefit of being relatively uncomplicated to grow in fermenters, therefore being appropriate for large scale production. Another benefit is the easy separation of fungal biomass by filtration because of its filamentous structure. In comparison to yeasts, filamentous fungi are less sensitive to variations in nutrients, aeration, $\mathrm{pH}$, temperature and have a lower nucleic content in the biomass (Leitão et al., 2009; Li et al., 2015).

\section{Conclusion}

In the present study, the sources of heavy metal ions as a toxic materials as well as the reason why they need to be removed from our environment have reviewed. Conventional methods of removal are expensive; hence the search of using low cost, friendly ecosystem material must be needed. From the above literature study, it is observed that biosorption is the most economical and eco-friendly method for removal of heavy metal from domestic as well as industrial wastewater. It is being an alternative to conventional methods for the removal of toxic heavy metals from industrial effluents. It offers several advantages including cost effectiveness, high efficiency, minimization of chemical/biological sludge, and regeneration of biosorbent with possibility of metal recovery. The process of biosorption has many attractive features including removal of metals over quit broad range of $\mathrm{pH}$ and temperature, its rapid kinetics of adsorption and desorption and low capital and operation cost. Biological biomass can be regenerated 
relatively easily and used again. Most significantly, the metal removal capacity of biological biomass is a good or better than other conventional adsorbents. The new biological - based technologies need not necessarily replace conventional treatment approaches but may complement them. So, the biosorption technology becomes more beneficial and attractive than currently used technologies.

\section{References}

Ademorati, C.M.A. "Pollution by Heavy metals," Environmental Chemistry and Toxicology, Foludex press Ibadan, pp. 171-172, 1996.

Ahalya, N., Ramachandra, T., Kanamadi, R. 2003. Biosorption of heavy metals. Res. J. Chem. Environ., 7: 71-79.

Ahalya, N., T. V. Ramachandra, and R. D. Kanamadi, "Biosorption of Heavy Metals," Res. J. Chem. Environ., vol. 7, pp. 71-79, 2003.

Aktan, Y., Tan, S., Icgen, B. 2013. Characterization of lead-resistant river isolate Enterococcus faecalis and assessment of its multiple metal and antibiotic resistance. Environ. Monit. Assess, 185: 5285-5293.

Baker, A., McGrath, S., Reeves, R.D., Smith, J. 2000. Metal hyperaccumulator plants: A review of the ecology and physiology of a biological resource for phytoremediation of metal-polluted soils. Phytoremediation of contaminated soil and water, 8: 85107.

Barrell, D.C. "Atomic Spectrophotometer Analysis of Heavy Metals Pollutants in Water," Ann Arbor Science Publishers Inc., Ann Arbor, MI, 1975.

Chaney, R.L., Angle, J.S., Broadhurst, C.L., Peters, C.A., Tappero, R.V., et al. 2007. Improved understanding of hyper-accumulation yields commercial phytoextraction and phytomining technologies. J. Environ. Quality, 36: 1429-1443.

Chen, J.M., and OJ. Hao, "Microbial chromium (VI) reduction," Critic. Rev. Environ. Sci. Technol., vol. 28, pp. 219-251, 1998.

Davis, J.A., B. Volesky, and RHSF. Vierra, "Sargassum seaweed as biosorbent for heavy metals," Wate Res., vol. 34(17), pp. 4270-4278, 2000.

Davis, T.A., Volesky, B., Mucci, A. 2003. A review of the biochemistry of heavy metal biosorption by brown algae. Water Res., 37: 4311-4330.

Fourest, E. and J.C. Roux, "Heavy metal biosorption bu fungal mycelial byproduct, mechanisms and influence of pH," Appl. Microbiol. Biotechnol., vol. 37, pp. 399-403, 1992.

Franke, S., Grass, G., Rensing, C., Nies, D.H. 2003. Molecular analysis of the copper-transporting efflux system CusCFBA of Escherichia coli. J. Bacteriol., 185: 3804-3812.

Gadd, G.M. "Metals, minerals and microbes: geomicrobiology and bioremediation," Microbiology, vol. 156, pp. 609-643. 2010.

Gadd, G.M. 2010. Metals, minerals and microbes: Geomicrobiology and bioremediation. Microbiol., 156: 609643.

Glombitza, F., Reichel, S. 2014. Metalcontaining residues from industry and in the environment: Geobiotechnological urban mining. Adv. Biochem. Eng. Biotechnol., 141: 49-107.

Godt, J.,F. Scheidig, Grosse-Siestrup C, Esche V, Brandenburg P, Reich A, Papandreou A, Stournaras CJ, and Panias D, "Copper and cadmium adsorption on pellets made from fired 
coal fly ash," J. Hazard. Mater., vol. 148, pp. 538-547, 2007.

Granados-Correa, F., and J. Serrano-Gomez, "CrO2 $2^{--} 4$ ions adsorption by $\mathrm{Fe}$ modified pozzolane," Sep. Sci. Technol., vol. 44, pp. 924-936, 2009.

Hrynkiewicz, K., Baum, C. 2014. Application of microorganisms in bioremediation of environment from heavy metals Environmental Deterioration and Human Health. Springer, 215-227.

Igwe, J.C., and AA. Abia, "Maiz Cob and Husk as Adsorbents fot removal of $\mathrm{Cd}$, $\mathrm{Pb}$ and $\mathrm{Zn}$ ions from wastewater," The Physical Sci., vol. 2, pp. 83-94, 2003.

Kasuya, M., H. Teranishi, K. Aohima, T. Katoh, N. Horignchi, Y. Morikawa, M. Nishijo, and K. Iwata, "Water pollution by cadmium and the onset of "itai-itai" disease," Water Sci. Technol., vol. 25, pp. 149-156, 1992.

Klaassen, C.D. "Heavy metals and Hardmen JG, Limbird LE, Gilman AG (eds). Goodman and Gilmans: The pharmacological Basis of Therapeutics," McGraw Hill, New York, pp. 1851-1875, 2001.

Kumar, R., Sharma, A.K., Singh, P., Dhir, B., Mehta, D. 2014. Potential of Some Fungal and Bacterial Species in Bioremediation of Heavy Metals. $J$. Nuclear Physics, Material Sci., Radiation and Applications 1: 213223.

Leitão, A.L. 2009. Potential of Penicillium species in the bioremediation field. Int. J. Environ. Res. Public Health, 6: 1393-1417.

Li, X., Li, A., Long, M., Tian, X. 2015. Equilibrium and kinetic studies of copper biosorption by dead Ceriporia lacerata biomass isolated from the litter of an invasive plant in China. $J$. Environ. Health Sci. Eng., 13: 37.
Macek, T., Kotrba P, Svatos A, Novakova M, Demnerova K, et al. 2008. Novel roles for genetically modified plants in environmental protection. Trends Biotechnol 26: 146-152.

Manohar, D.M., K.A. Krishnan, and T.S. Anirudhan, "Removal of mercury (II) from aqueous solutions and chloralkali industry wastewater using 2mercaptobenzimidazole-clay," Water Res., vol. 36, pp. 1609-1619, 2002.

Muyzer, G., Stams, A.J. 2008. The ecology and biotechnology of sulphatereducing bacteria. Nat. Rev. Microbiol., 6: 441-454.

Neethu, C.S., Mujeeb Rahiman, K.M., Saramma, A.V., Mohamed Hatha, A.A. 2015. Heavy-metal resistance in Gram-negative bacteria isolated from Kongsfjord, Arctic. Can. J. Microbiol., 61: 429-435.

Onundi, Y.B., A.A. Mamun, M.F.Al Khatib, and Y.M. Ahmed, "Adsorption of copper, nickel and lead ions from synthetic semiconductor industrial wastewater by palm shell activated carbon," Int. J. Environ. Sci. Tech. Autumn, vol. 7(4), pp. 751-758, 2010.

Ozturk, A. "Removal of nickel from aqueous solution by the bacterium Bacillus thuringiensis," J. Hazard. Mater., vol. 147, pp. 518-523, 2007.

Pandit, R., Patel, B., Kunjadia, P., Nagee, A. 2013. Isolation, characterization and molecular identification of heavy metal resistant bacteria from industrial effluents, Amala-khadi-Ankleshwar, Gujarat. Int. J. Environ. Sci., 3: 5.

Pendias, H., and A. Kabata-Pendias, "Trace Metals in Soil and Plants," CRC press, Boca Raton, FL, pp. 75-86, 1992.

Petersen, F., C. Aldrich, A. Esau, and B.C. 2005. Qiiii, "Biosorption of Heavy Metals from Aqueous Solutions," WRC Report, vol. 1, iss. 100. 
Robertson, F.N. "Arsenic in ground water under oxidizing conditions, southwest United States," Environ. Geochem. Health, vol. 11, pp. 171-176, 1989.

Schumann, K. "The toxicological estimation of the heavy metal content $(\mathrm{Cd}, \mathrm{Hg}$, $\mathrm{Pb}$ ) in food for infants and small children," Z. Ernahrungswiss, vol. 29, pp. 54-73, 1990.

Sharma, Y.C. "Economic treatment of Cadmium (II)-rich hazardous waste by indigenous materials," J. Colloid Interfac. Sci., vol. 173, pp. 66-70, 1995.

Singh, K.K., A.K Singh, and S.H. Hasan, "Low cost bio-sorbent, ,wheat bran" for the removal of cadmium from wastewater: kinetic and equilibrium studies," Biores. Technol., vol. 97, pp. 994-1001, 2006.

Singh, S., Kang, S.H., Mulchandani, A., Chen, W. 2008. Bioremediation: Environmental clean-up through pathway engineering. Curr. Opin. Biotechnol., 19: 437-444.

Volesky, B. 1994. "Advances in biosorption of metals: selection of biomass types," FEMS Microbiol. Rev., vol. 14, pp. 291-302.

Volesky, B. 2007. "Biosorption and me," Water Res., vol. 41, pp. 4017-4029.

Volesky, B. and Holan, Z. 1995. "Biosorption of heavy metals," Biotechnol. Progr., vol. 11, pp. 235250.
Wagoner, J.K. and U. Soffioti, "Occupational Carcenogenesis," New York Academy of Science, p. 271, 1976.

Wang, J., Chen, C. 2009. Biosorbents for heavy metals removal and their future. Biotechnol. Adv., 27: 195-226.

Wang, J.L., and C. Chen, "Biosorbents for heavy metals removal and their future a review," Biotechnol. Adv., vol. 27, pp. 195-226, 2009.

Wang, J.L., and C. Chen, "Biosorption of heavy metals by Saccharomyces cerevisiae: a review," Biotechnol Adv., vol. 24, pp. 427-451, 2006.

Wang, J.L., C. Chen. 2009. "Biosorbents for heavy metals removal and their future a review," Biotechnol. Adv., vol. 27, pp. 195-226.

Yasuda, M., A. Miwa, and M. Kitagawa, "Morphometric Studies of renal lesions in "Itai-itai" disease: chronic cadmium nephropathy," Nephron, vol. 69, pp. 14-19, 1995.

Yingh, C.P. "Biosorption of copper(II) and chromium(VI) onto activated sludge: isotherms and kinetic models," M.Sc. Thesis, University Sains Malaysia, Malaysia, June 2007.

Zabochnicka-Åšwi, Ä., tek, M., Krzywonos, M. 2014. Potentials of Biosorption and Bioaccumulation Processes for Heavy Metal Removal. Mercury, 6: 145.

\section{How to cite this article:}

Kalyani, P., and Hemalatha, K.P.J. 2016. Biosorption of Heavy Metals in the Environment-A Review Paper. Int.J.Curr.Res.Aca.Rev.4(11): 66-74. doi: http://dx.doi.org/10.20546/ijcrar.2016.411.011 